\title{
Exploring Pre-Service EFL Teachers' Beliefs About Their Roles in an Elementary School Classroom in Regard to Pedagogical and Emotional Aspects of Students
}

\section{Exploración de las creencias de docentes de inglés en formación acerca de su papel en relación con aspectos pedagógicos y emocionales de sus estudiantes en el salón de clases*}

\author{
Iván Aguirre Sánchez \\ aguirreivan@unbosque.edu.co \\ Universidad El Bosque, Colombia
}

This article aims at exploring the beliefs of a group of pre-service teachers from a B.Ed. program in Bilingual Education in Bogotá (Colombia), regarding their role as teachers in some general pedagogical and emotional aspects of their primary school students inside the classroom. They were observed over 16 weeks during their pre-service practice and were asked to submit weekly log entries with pedagogical reflections on their performance. Results show that these pre-service teachers believe motivation and identification of their students' academic needs to be their main role inside the classroom.

Key words: Beliefs, EFL teachers' reflections, pedagogical and emotional aspects, primary school students, role

Este artículo se exploran las creencias de un grupo de futuros docentes, estudiantes de un programa de licenciatura en Educación Bilingüe en Bogotá (Colombia), en torno al papel que ellos desempeñan en algunos aspectos pedagógicos generales y emocionales de sus estudiantes en el aula de clase. Estos futuros educadores fueron observados en su desempeño durante 16 semanas de práctica, pidiéndoles hacer un diario de campo con reflexiones pedagógicas de cada sesión de práctica. Los resultados muestran que estos futuros docentes consideran la motivación y la identificación de sus necesidades académicas, como su papel principal en los aspectos mencionados.

Palabras clave: aspectos pedagógicos y emocionales, creencias, estudiantes de primaria, papel, reflexiones de docentes de inglés

Received: October 30, 2013. Accepted: February 1, 2014. 
Exploring Pre-Service EFL Teachers' Beliefs About Their Roles in an Elementary School Classroom in Regard to Pedagogical and Emotional Aspects of Students

\section{Introduction}

There are different types of teachers in all fields of knowledge. Each one of them is the sum of academic formation, learning-teaching experiences, beliefs about education, society, and so forth, which become evident in their everyday teaching practices. All these aspects largely determine what teachers do in the classroom, how they teach, evaluate, and address their students.

This research project is focused on identifying the beliefs of a group of pre-service English as a foreign language (EFL) teachers about the role they play in some general pedagogical and emotional aspects of their students inside the classroom. I decided to do the project from the pre-service stage in order to determine these beliefs from such an early moment of their process to become teachers.

\section{Literature Review}

\section{The Teacher: Role and Beliefs}

Teacher's role. This section will deal with concepts such as all-round education, motivation, autonomy, and critical thinking.

There are many ideas regarding the role a teacher is supposed to play in the classroom. In fact, every single teacher has his or her own idea which impacts his or her pedagogical practice. Let us see what different authors state, as well as review some research that has been conducted about teachers' roles and beliefs.

The concept about the role that teachers play in the classroom has evolved through the years. The role of current teachers is not teaching (understood as explaining-examining) anymore, but helping students to "learn how to learn" in an autonomous way (Marqués, 2000, Funciones de los docentes hoy, para. 2). He also states teachers need to promote both cognitive and personal development through critical and explicative activities that, taking advantage of information and technology, demand active and interdisciplinary information processing from students in order to build their own knowledge.

Other scholars believe that the role of teachers must impact beyond the classroom. Learners are to be given the right tools to analyze our society critically, so that they become able to transform it. In that sense, Freire (1990) understands the role of teachers as proposing problems around coded existential situations that may lead learners to reach a critical view of their own reality. Thus, the educator's responsibility is larger in every sense regarding those teachers whose role is to transmit information for students to memorize. 
Another aspect of teaching that impacts beyond the classroom is what educators call all-round education, or education addressing all human dimensions. In this sense, Delors (1996) proposed the four pillars of education as part of the report to UNESCO of the International Commission of Education for the Twenty-First Century. These pillars are described as follows and are intended to address such dimensions:

- Learning to know: This pillar is assumed as both a means and an end of human existence. Understood as a means, people need to know how to understand the surrounding world in a way they can lead their lives with some dignity, acquire and evolve their working capacity, and establish communication with other people. Understood as an end, it refers to the pleasure of understanding, knowing, and discovering.

- Learning to do: It refers to personal competence, as opposed to certified skills to do very specific tasks.

- Learning to live together: Education must teach people to understand the concept of human diversity and how we are similar and interdependent. Additionally, we should teach people from their early childhood to look at things from their own perspective so they can understand other people's reactions.

- Learning to be: A man will fulfil his purpose in life when developing his personality, the way he expresses himself and his commitment as a person and as part of a family, a given community, citizen, creator of techniques, and so forth.

As can be seen, the four pillars aim at addressing most of what a human being is expected to be in our society nowadays.

A study regarding the concept of a group of professors in a School of Health in relation to their students' all-round education was conducted at a Colombian university (Angulo, González, Santamaría, \& Sarmiento, 2007). The model projected by their professors during their formation process exerts a strong influence in the way they teach. The functions performed by these educators are grouped in the following two categories:

- Model: Professional formation, experience, coherent, and image (personal and institutional).

- Tutor: Emotional support, orientation, formation in values.

In this sense, it can be said that a great deal of what we as educators are, is connected to the pedagogical experiences we live during our student-teacher years.

Autonomy seems to play a key role in what a teacher is supposed to promote inside the classroom. In this respect, Mora (1994) argues that decision making is an ability that can be acquired, but a previous training stage is necessary. He affirms that, in general terms, a teacher is required to have both a good language management and solid methodological bases in 
Exploring Pre-Service EFL Teachers' Beliefs About Their Roles in an Elementary School Classroom in Regard to Pedagogical and Emotional Aspects of Students

order to be able to contribute with appropriate and scientifically justified answers to language learning difficulties.

Campo (2002) states a similar viewpoint regarding students' autonomy achievement and the role played by teachers in the process. She argues that the role of the teacher needs to lead them to autonomy regarding their learning in order to become independent thinkers and problem solvers.

Concerning what happens inside the classroom, Ahmed (2009) proposes the teacher be a mediator when students misunderstand new tasks. She believes teachers should help students elaborate on what they already know, stimulating them to consider different options to solve a given problem. This means there is a lot more to teaching than just the transmission of knowledge, as usually happened in the past. A teacher is there to help the learner find his own way to learn.

Besides the study on all-round education mentioned before, a number of research experiences have found several relevant factors related to the role played by teachers in the classroom. Blanco (2005) intended to determine the teacher's role in a class of Spanish as a foreign language for Brazilian university students. She found participation and constant negotiation to be main features of teacher-student interaction. Additionally, the teacher's role is that of a guide and moderator with her/him making constant efforts to motivate students to make the activity (text analysis) "theirs," transforming it by means of contributing with their own ideas.

Among the most fundamental features in education, motivation plays a key role because it can help students' attitude towards their learning process to become positive. In some cases, motivation is commonly understood as "feeling connoting emotional or visceral reactions versus cognitive dimensions such as thinking” (O’Neil \& Drillings, 1994, p. 3).

Biehler and Snowman (2003) believe motivation to be all energies that intervene in causing a behavior. They also believe that teachers commonly have two misconceptions about motivation in education as follows:

1. Students are unmotivated: In this respect, they state that what teachers really mean is they would like students to behave in certain ways, but students are demotivated to behave in such ways.

2. One person can directly motivate another: This is wrong to them because they understand motivation to originate inside people, and what teachers can do is to create situations that lead learners to act the way teachers want.

Besides defining motivation, other authors identify different types of it. Harmer (as cited in Wang, 2009) distinguishes two types of motivation in language learning: extrinsic and intrinsic. The first one refers to factors outside the classroom, while the second one relates to 
factors inside the classroom. It can be considered that extrinsic motivation might be part of a teacher's role in the classroom.

Davis (1993) highlights the role of the teacher in motivating students through three specific aspects as follows: (a) capitalize on students' existing needs, (b) make students active participants in learning, and (c) ask students to analyze what makes their classes more or less "motivating" (p. 794).

There are, however, those who believe motivating students is not part of teachers' primary responsibilities. Martin (2009) states that we as teachers must pay attention to students' needs, particular interests and their differences, which will facilitate motivation to take place.

From his own experience, the researcher understands motivation as a decisive aspect among all the strategies a teacher can implement in the classroom. It helps students to become more interested in class topics, as well as it can impact their understanding and performance regarding expected outcomes. As we can see, there are different perspectives regarding a teacher's role in the classroom and they relate to concepts such as all-round education, motivation, autonomy, and critical thinking.

Pre-service teachers' beliefs. Although this is considered a difficult concept to define, the Cambridge Dictionary of American English defines belief (2003) as "the feeling of being certain that something exists or is true" (p. 73).

Pajares (1992) thinks this is a "messy concept," whose main problem comes from establishing a clear difference between belief and knowledge, but defines it as "an individual's judgment of the truth or falsity of a proposition, a judgment that can only be inferred from a collective understanding of what human beings say, intend, and do" (p. 316).

Nespor (as cited in Zheng, 2009), states that

Beliefs reside in episodic memory of which the content is generated by earlier experiences, episodes, or from cultural sources of knowledge transmission. This rather affective and emotional aspect of beliefs plays an important part in storing, assimilating and retrieving knowledge by evaluating and judging gathered information. (p. 74)

During the last decades, research in education has expanded its horizons, addressing a wide range of related aspects. Particularly, in-service and pre-service teachers' beliefs has become a usual topic in educational research, whose impact may affect in a number of ways the different programs dedicated to train future teachers, as well as in-service teachers' reflection on their performance.

Normally, pre-service EFL teachers have some beliefs regarding language learning, mostly based on their personal experiences when they were at school. It is important for them to be open-minded so such beliefs may change or evolve as they are trained as future teachers. 
Exploring Pre-Service EFL Teachers' Beliefs About Their Roles in an Elementary School Classroom in Regard to Pedagogical and Emotional Aspects of Students

A research conducted by Peacock (2001) in the Department of English at the University of Hong Kong reports on the changes in the beliefs about second language learning of pre-service English as a second language (ESL) teachers. The study began with the hypothesis that future teachers would have mistaken ideas about what ESL teaching was, and how it could have happened. On the other hand, it also began with the hypothesis that after taking courses related to language teaching, students would change and restructure their beliefs. Data showed that after collecting the inventory of the students attending the first year, nothing changed regarding the positions about ESL teaching when they were in second or third year. Later, the researches decided to design and apply a document for working on their beliefs and this led to some changes.

The conclusions gathered by another study focusing on professional growth among pre-service teachers pointed out that there should be continuous and repeated efforts during their learning process to affect pre-service teachers' beliefs in a positive way. For this reason, it is also relevant to state that when future ESL teachers begin the course with clear conceptions about teaching and teachers focusing on self-reflective approaches, the teaching performances are reinterpreted (Kagan, 1992).

R. de Moreno (2002) conducted a qualitative exploratory study to identify which conceptions of pedagogical practice the practicing students, regular students, teachers and advisers have in a social studies undergraduate program at a public university in Bogotá. She states that beliefs are experiential knowledge represented in images or mental constructs of an intersubjective, personal, and situational nature. She also argues that, besides this experiential knowledge, teachers possess meanings explicitly acquired during their formation process.

In order to determine the role of beliefs in a teacher, it is pertinent to identify where these beliefs come from. Álvarez (2009) explored this issue regarding Colombian EFL teachers in a qualitative research. He found that "beliefs, values, and knowledge are not static constructions; on the contrary, they are the product of continuous influences of people, learning and teaching experiences in different moments of the teachers' life" (p. 86).

In the same local context, Castellanos (2013) conducted a project in Colombia presenting a review of several studies on pre-service teachers' beliefs about teaching. She found that "teacher educators should keep in mind the premise that student teachers enter a teacher education program with beliefs about teaching, and explicitly integrate it in their syllabi through reflection, course content and learning activities" (p. 203). In that sense, teachers' beliefs may not only be shaped by the theoretical component of the programs they take, but also by their own life experiences.

Pre-service teachers' beliefs may start being shaped even before they decide to become teachers. However, many events that take place during pre-service practice might also impact such beliefs, which may contribute to define their identity as teachers. In this respect, Díaz 
(2013) conducted a study at a public university in Colombia. She found that pre-service teachers portray their identity through the actions and decisions they engage in at school as a result of their day-to-day interactions with the context. After analyzing pre-service teachers' reflections, diaries, and her own observations, Díaz found identity to be a collective development that is elaborated in the places where individuals obtain knowledge and cooperate with one another.

As time passes, new elements are being incorporated to education. Technology is one of them and teachers' beliefs on that issue also play a key role as to how relevant these aids can be in the classroom. García and Rey (2013) studied how such beliefs impact the use of this type of resources in the EFL class at a private university in Barranquilla, Colombia. Through observation of English teachers, the researchers learned that most of them use technology as a means of low level tasks to reinforce topics introduced during class sessions. Results of this research suggest that participants believe they are using information and communication technology (ICT) adequately and they perceive ICT to be a fundamental aspect in the effectiveness of teaching and the success of students' learning. They also believe ICT not only helps attain educational goals, but also motivates students to learn.

In the international context, Lim and Chan (2007) conducted a study at the National Institute of Education in Singapore. Their purpose was to get pre-service teachers' beliefs closer to the constructivist approach and far from the traditional one through something they called microLESSONS when designing multimedia learning packages. The results of the study showed that future teachers became more confident when designing those packages based on the constructivist approach, although their beliefs were not really affected by this type of short effort and they were reluctant to change them.

The two studies presented above concluded that pre-service teachers' beliefs are not easy to affect unless the subjects are constantly and systematically exposed to a number of theoretical concepts that question the ones they already know.

Both studies were not alone in the consideration of several issues that needs to be taken into account when trying to influence the pre-service teachers' beliefs. For instance, a study developed by Mattheoudakis (2007) with English language teaching (ELT) pre-service teachers and their beliefs about learning and teaching in Greece was also taken into consideration. She found out that the impact of the education program on those beliefs was progressive and, in some cases, relevant. Nevertheless, the impact of their teaching practice on them is low. This study was conducted within a three-year education program for ELT teachers and suggests that its results could be useful when designing other similar programs.

On the other hand, some other authors have found an impact in beliefs after some courses taken within educational programs. Fischl and Sagy (2005) conducted research whose purpose was to establish the pre-service teachers' beliefs about teachers and teaching before 
Exploring Pre-Service EFL Teachers' Beliefs About Their Roles in an Elementary School Classroom in Regard to Pedagogical and Emotional Aspects of Students

and during their training period. Results suggest that even though pre-service teachers began the program with general and non-clear conceptions about teaching and teachers, they were affected and presented several changes along the process. Those changes were related to the belief that the school was giving children tools that could help them socially, some opinions they had had before to which they added new professional information and their perception about the teachers' characters.

Prospective teachers are former students and their previous experiences are linked to any subject they are learning, the way it is taught and learnt, and how those experiences influence their beliefs about it. For this reason, it is important to help future teachers to "learn to do something different from and better than what they have experienced in previous classes" (Ball, 1990, p. 11).

Educators have a big responsibility assisting pre-service teachers to achieve the goals they want to in relation to the content, knowledge, and process of teaching. In certain institutions, some teaching styles and practices are preferred, but Brindley (1984) points out that teachers who favor a "learner-centered" view of learning, which consists of acquiring and organizing principles through experiences, and that students who avoid the assumptions that teachers are measured in terms of the knowledge they impart, would probably change those wrong beliefs. After being exposed to different theories which in most cases are new, students restructure their beliefs and become more confident.

Based on the previous theories and research, it may be concluded that the amount of time invested in creating an impact in pre-service teachers' beliefs should be a goal to achieve before designing the procedure of a new study.

\section{Research Framework}

This project was implemented during 16 weeks within the subject Pedagogical Practice IV (with primary school children from a public co-educational school in its afternoon shift located in the north east of Bogotá).

Participants were observed during their pre-service practice in order to try to identify their beliefs regarding their role as teachers in some general pedagogical and emotional aspects of their students inside the classroom. Additionally, they were asked to keep a teacher's log focusing on their general reflections after teaching each session at the school.

\section{Resources}

This project used a number of resources consisting of materials and technological aids such as personal digital assistant (PDA) or laptop to collect and analyze class observations on the spot and laptop and e-mail to receive pre-service teachers' log entries. 


\section{Researcher's Role}

The role played by the researcher during the project implementation was that of teacher-researcher. The researcher was in charge of collecting student-teachers' log entries on a weekly basis during the implementation and observing participants' performance during class sessions.

Besides the particular role played during the implementation of the project, the researcher also plays the role of instructor of this subject, providing qualitative feedback on pre-service teachers' performance.

\section{Method}

This project aimed at determining the participants' beliefs on their role as teachers in their primary school students' general pedagogical and emotional aspects inside the classroom.

The research question that guided this study was:

- What are the beliefs of a group of pre-service teachers from a teacher training program in Bilingual Education regarding their role as teachers in some general pedagogical and emotional aspects of their primary school students inside the classroom?

Objective:

- To identify the beliefs of a group of pre-service teachers from a teacher training program in Bilingual Education regarding their role as teachers in some general pedagogical and emotional aspects of their primary school students inside the classroom.

\section{Type of Study}

This was a qualitative research project as it was intended to identify people's perceptions and beliefs. More especifically, it was a case study, which is "an intensive description and analysis of a phenomenon or social unit such as an individual, group, institution or community" (Merriam, 2002, p. 8). This author also states that a case study aims at describing a phenomenon in depth (which is called the case).

Cohen and Manion (as cited in Nunan, 1995) explain that in a case study, the researcher observes the characteristics of a student, a class or a school (the unit of analysis) in order to make generalizations about such population.

Case study research was considered to be appropriate for this research project because the main purpose of it was to observe the participants' natural behavior in their place of learning and pre-service practice. 
Exploring Pre-Service EFL Teachers' Beliefs About Their Roles in an Elementary School Classroom in Regard to Pedagogical and Emotional Aspects of Students

\section{Context}

This study was conducted during the pre-service practice of a teacher training program at a private university in Bogotá, Colombia. The program is aimed at teaching children and teenagers.

The implementation of this project took place at a public co-educational school located in the northeast of Bogotá in the zone called Usaquén, with which the teacher training program had a pre-service teaching agreement when the project was implemented. This school educates children and teenagers in the morning and afternoon shifts, and adults in the evening shift. For this project the afternoon shift was chosen as it matched the program shift at the university (afternoon), and the participants taught at the primary level because that is the population corresponding to the particular subject. Students live close to the school and belong to a lower socio-economic status.

\section{The Participants}

The participants in this study were six students from eighth semester, all of them young adults whose ages ranged from 20 to 35 . None of them had previous teaching experience and all came from the lower middle class.

Their English proficiency was certified B1 according to the Common European Framework of Reference for Languages through a proficiency test administered by the University Language Centre.

\section{The Instruments}

The instruments for data collection were as follows:

Field notes through an observation scheme designed form (OSF). This OSF was divided into two columns. In the left column everything observed during the sessions regarding participants' behavior and interaction was written, while in the second or right column comments and insights about those being observed (raw notes and cooked notes) were registered.

Teachers' log: This instrument consisted of a type of diary in which participants wrote freely their insights and reflections about both their pre-service practice and their role as teachers in some general pedagogical and emotional aspects of their primary school students.

All data including transcriptions of two observations per each of the six participants, as well as eleven student-teachers' log entries-all collected during a whole semester-were classified and organized by computer so that each commonality was easily identified by means of analysing possible patterns and comparing and contrasting the arising features. As soon as 
patterns appeared, they were put together into preliminary groups that, later on, were refined into a category.

\section{Data Analysis}

All the information gathered was organized onto magnetic storage media in a computer, and the data analysis began by the reading of each piece of information provided by the participants. During data analysis, patterns emerged and were interpreted and then each one given a name. They were then put together in broader topics to form the category that answered the research question. Such category was described, exemplified, and supported with both previous research and theory in the field. The researcher followed the data analysis model proposed by Patton (1987) in terms of organizing data, reducing it through summarization and categorization, and identification and linkage of emerging patterns.

Participants' concern as to students' well-being during class sessions shaped the category that emerged from data analysis:

\section{Taking Care of Students' Well-Being Through Motivation and by Identifying Their Academic Needs}

This group of pre-service teachers serve as emotional support for their students. It is seen in the way they interact with their students and how they analyze what happens in the classroom. It partially matches what Angulo et al. (2007) found in some research in which the authors intended to determine the concept of all-round education among a group of professors at a university's School of Health regarding their students, and how such concept shaped their teaching performance. The roles performed are described in two categories, one of which refers to being a tutor. That is, emotional support, orientation, and formation in values.

This first example corresponds to Student 3's log entry from the third session:

In this time of practice have been analyzing about student needs, but not only academic needs, if not emotional needs, the first day of class the teacher told me these students (some) are terrible you need be devotes and be strong with them.

Always I have had curiosity by discover why some children or some people act of bad way? For example I the course the teacher told me specifically about a girl, she told me "Take care with that girl she don't work in class" ok, is true that in any moment you as a teacher is to the defensive, but when I begun to delegated work in the class, that girl come to me and showed me her work and including the other (terrible children).

Really I can discovered what were happening with these children, number one; they have lack of love. The role of a teacher goes beyond of the academic, and a teacher can change the student's life. [sic] (Student 3, Log Entry, Class 3) 
Exploring Pre-Service EFL Teachers' Beliefs About Their Roles in an Elementary School Classroom in Regard to Pedagogical and Emotional Aspects of Students

This prospective teacher is concerned with students' emotional needs. She describes how paying attention to misbehaving children i.e. providing special attention to them may impact their behaviour in a positive way. Consequently, she pays special attention to those of her students who present inappropriate behaviours and tries to make a difference in such students, not only in academic terms but in personal ones as well.

The following example belongs to class observation. Specifically, this one concerns Student 1 during the first time she was observed:

Right before the class starts she tells me her students like English a lot and she is like an idol for them...She tells them they are quite well behaved. (Participant 1, Observation 1)

As can be observed, this prospective teacher believes there is a connection between her students' fondness for her subject and the positive way they perceive her. This connects to what Díaz (2013) found in her study at a public university in Colombia when she mentions the value of the "reflection on teachers as models and the replication of these models in student-teachers' identity" (p. 47). Besides, in the case of the particular example analyzed, this pre-service teacher starts her class highlighting her students' positive behavior. Telling students positive things about themselves may strengthen ties between teachers and students.

This next example belongs to the second class observation:

A student asks for a word written on the board, and you encourage him to find it himself. (Participant 4, Observation 2)

This pre-service teacher understands her role in relation to fostering students' autonomy, which matches what Campo (2002) states regarding the teacher's role, as someone who helps them take contror of their own learning process. In this particular case, the pre-service teacher helps her students to become aware of the fact that they can play an active role in their learning process.

The following example of this category belongs to another participant in her second class observation:

You praise their right answers with "very good." Your tone of voice with your students is very kind and sweet. (Participant 5, Observation 2)

As Dörnyei (2001) states, most of a teacher's effectiveness relates to motivating learners. Addressing students in an appropriate way may impact their motivation and, consequently, their classroom performance. This pre-service teacher seems to believe students need motivating words, which she accompanies with a gentle tone of voice praising her students' efforts and facilitating a positive class environment.

This next example belongs to another participant during her second class observation: 
You call a student by her first name and tell her she will be your monitor because she got the highest score in the quiz. You congratulate her praising her effort with an "excellent," and request her class to clap. (Participant 1, Observation 2)

Praising students' efforts in public, as well as assigning roles of responsibility might have a positive impact on a class. This pre-service teacher seems to understand the pertinence of this type of actions inside the classroom and its impact on students' motivation and attitude towards the class.

This following example belongs to a log entry written by a student regarding her tenth class session:

Well at time when started to use the watch they looked like emotional, so I think I am doing my job in a good way, it is reflected on the students' motivation and learning. [sic] (Participant 1, Log Entry, Class 10)

To this pre-service teacher, students' emotional responses provide evidence of active participation and cause her to think she is doing her job appropriately. She connects class participation with motivation. Then, she establishes a relationship between these two factors with the goal of learning.

This example comes from a student's second session log entry:

The activity, was very productive, since changes the methodology of the class, which was it of always, we made something didactic and they amused themselves very much, while at the same time they were learning vocabulary and to identify words by means of the listening...With regard to me, I am glad be able to have carried out a not prepared class and I feel a lot of satisfaction that my students enjoyed and learned of it. [sic] (Participant 5, Log Entry, Class 2)

To this pre-service teacher, changes in methodological terms may have a positive impact on students' responses and learning. She understands amusement can potentially become a positive factor to facilitate learning inside the classroom. In this particular case, she used a song to vary her traditional class methodology, perceiving a beneficial effect in her class.

Similarly, this following example deals with methodological changes and their impact on students' motivation and attitude towards the class. In her log, this pre-service teacher points out that:

My tutor told me they are much undisciplined and for that reason, they always should work in sheets from guidebook... and I do not like it. I sometimes think they should play, I mean, use a game for the learning. In other hand, while we are on class, in front of the classroom there is a yard, and that space is been used for the rest of high school, so my children do not pay attention because of the noise.

I think...this children are all the time sit down in their desk and maybe the think study is bored, I want they should English in another idea, sometime fun, which can be useful in their lives. [sic] (Participant 6, Log Entry, Class 1) 
Exploring Pre-Service EFL Teachers' Beliefs About Their Roles in an Elementary School Classroom in Regard to Pedagogical and Emotional Aspects of Students

She analyzes what she believes to be the origin of disciplinary issues with her class when she states her belief regarding the relevance of using games with a pedagogical purpose. She thinks language learning should be fun so students do not feel bored and take advantage of the class.

\section{Conclusions and Implications}

From the project findings it can be concluded that it is a good idea for language teachers to consider the importance of the emotional component (represented in how our students feel and how we make them feel in our classes) as part of successful teaching. It is also applicable to the fact that sometimes academic needs are closely related to emotional needs and it is the teacher's role to be able to detect both of them and, as in this case, identifying the latter leads to learning about the former.

For most participants in this project, students' well-being plays a paramount role and it is represented in what they can do as teachers to motivate and identify what students need in academic terms.

The results of this study imply the relevance of motivation and identification of students' needs that we as teachers have to bear in mind when teaching. They entail that teachers' beliefs impact what they do in the classroom and how they interact with their students. They also imply that the role of the teacher not only refers to preparing classes in advance, but also to analyzing our students in situ, their characteristics, their feelings and emotions towards us as teachers and the subject we teach. In that way, our role can become more effective in causing learning to take place.

\section{References}

Ahmed, A. (2009). Teachers' role in improving students' thinking skills: moving beyond the "sage on the stage." Teachers.Net Gazette, 6(3). Retrieved from http://teachers.net/gazette/ MAR09/ahmed/

Álvarez, J. A. (2009). An exploration of Colombian EFL teachers' knowledge base through teachers' reflection. Linguagem \& Ensino, 12(1), 73-108.

Angulo, B., González, L. H., Santamaría, C., \& Sarmiento, P. (2007). Formación integral de los estudiantes: percepción de los profesores de la Facultad de Salud de la Universidad del Valle [Total development of the students: Perceptions of the teachers of the School of Health, Universidad del Valle]. Colombia Médica, 38(4), 15-26.

Ball, D. L. (1990). Breaking with experience in learning to teach mathematics: The role of a preservice methods course. For the Learning of Mathematics, 10(2), 10-16.

Belief. (2003) In Cambridge Dictionary of American English (4th printing). Cambridge, UK: Cambridge University Press. 
Biehler, R. F., \& Snowman, J. (2003). Psychology applied to teaching (10th ed.). Boston, MA: Houghton Mifflin.

Blanco, E. (2005). El papel del profesor: análisis de dos sesiones de clase de ELE. [The role of the teacher: Analysis of two ELE class sessions]. Revista RedELE, 3(3). Retrieved from http://www.mecd.gob.es/dctm/redele/Material-RedEle/Revista/2005_03/2005_redELE_ 3_06Blanco2.pdf?documentId=0901e72b80e06378

Brindley, G. P. (1984). Needs analysis and objective setting in the adult migrant education program. Sydney, AU: N.S.W. Adult Migrant Education Service.

Campo, E. (2002). Towards an integrated approach to foreign language learning. Folios, 16, 95-102.

Castellanos, J. (2013). The role of English pre-service teachers' beliefs about teaching in teacher education programs. PROFILE Issues in Teachers' Professional Development, 15(1), 195-206.

Davis, B. G. (1993). Tools for teaching. San Francisco, CA: Jossey-Bass.

Delors, J. (Chair) (1996). Learning: The treasure within. Report to UNESCO of the International Commission for Education of the Twenty-first Century. Paris, FR: UNESCO.

Díaz, D. M. (2013). The way student-teachers construct their identity at schools. HOW, A Colombian Journal for Teachers of English, 20(1), 36-50.

Dörnyei, Z. (2001). Teaching and researching motivation. Harlow, UK: Pearson Longman.

Freire, P. (1990). La naturaleza politica de la educación: cultura, poder y liberación [The political nature of education: Culture, power, and liberation.]. México, MX: Paidós.

Fischl, D., \& Sagy, S. (2005). Beliefs about teaching, teachers, and schools among pre-service teachers: The case of Israeli-Bedouin students. Language, Culture and Curriculum, 18(1), 59-71.

García, M., \& Rey, L. (2013). Teachers' beliefs and the integration of technology in the EFL class. HOW, A Colombian Journal for Teachers of English, 20(1), 51-72.

Kagan, D. M. (1992). Professional growth among pre-service and beginning teachers. Review of Educational Research, 62(2), 129-169.

Lim, C. P., \& Chan, B. C. (2007). MicroLESSONS in teacher education: Examining pre-service teachers' pedagogical beliefs. Computers and Education, 48(3), 474-494.

Marqués, P. (2000). Los docentes: funciones, roles, competencias necesarias, formación [The Teachers: Functions, roles, necessary competences, formation]. Barcelona, ES: Universidad Autónoma de Barcelona. Retrieved from http://www.peremarques.net/docentes2.htm

Martin, R. (2009). Fostering motivation through differentiated instruction in ELT. Paper presented at the English Language Teaching Conference, Sultan Quaboos University, Oman. Retrieved from http://www.docin.com/p-375877224.html

Mattheoudakis, M. (2007). Tracking changes in pre-service EFL teacher beliefs in Greece: A longitudinal study. Teaching and Teacher Education: An International Journal of Research and Studies, 23(8), 1272-1288.

Merriam, S. B. (Ed.). (2002). Qualitative research in practice: Examples for discussion and analysis. San Francisco, CA: Jossey-Bass.

Mora, M. A. (1994). El papel del profesor en la autonomía del aprendizaje del alumno de español como lengua extranjera [The teacher's role in learner autonomy of the student of Spanish as a 
Exploring Pre-Service EFL Teachers' Beliefs About Their Roles in an Elementary School Classroom in Regard to Pedagogical and Emotional Aspects of Students

foreign language]. ASELE: Actas V, 219-226. Retrieved from http://cvc.cervantes.es/ ensenanza/biblioteca_ele/asele/pdf/05/05_0217.pdf

Nunan, D. (1995). Research methods in language learning. Cambridge, UK: Cambridge University Press.

O’Neil, H. F., Jr., \& Drillings, M. (1994). Motivation: Theory and research. Hillsdale, NJ: Lawrence Erlbaum Associates.

Pajares, M. F. (1992). Teachers' beliefs and educational research: Cleaning up a messy construct. Review of Educational Research, 62(3), 307-333.

Patton, M. Q. (1987). How to use qualitative methods in evaluation. London, UK: Sage.

Peacock, M. (2001). Pre-service ESL teachers' beliefs about second language learning: A longitudinal study. System, 29(2), 177-195.

R. de Moreno, E. A. (2002). Concepciones de práctica pedagógica [Conceptions on pedagogical practice]. Folios, 16, 105-129.

Wang, B. (2009). Motivation and language learning. Asian Social Science, 5(1), 98-100. Retrieved from http://www.ccsenet.org/journal/index.php/ass/article/viewFile/541/522

Zheng, H. (2009). A review of research on EFL pre-service teachers' beliefs and practices. Journal of Cambridge Studies, 4(1), 73-81.

\section{The Author}

Iván Aguirre Sánchez holds a B.A. in Modern Languages and an M.A. in Applied Linguistics to TEFL, both from Universidad Distrital, Colombia. His experience includes teaching in schools and at the higher education level. He is Director of the Bilingual Education program at Universidad El Bosque, Colombia. 